\title{
Is consent in medicine a concept only of modern times?
}

P Dalla-Vorgia, J Lascaratos, P Skiadas and T Garanis-Papadatos National University of Athens Medical School, International Hippocratic Foundation and the National School of Public Health, Athens, Greece

\begin{abstract}
Although the issue of consent in medical practice has grown immensely in recent years, and it is generally believed that historical cases are unknown, our research amongst original ancient Greek and

Byzantine historical sources reveals that it is a very old subject which ancient philosophers and physicians have addressed. Plato, in ancient Greece, connected consent with the quality of a free person and even before him, Hippocrates had advocated seeking the patient's cooperation in order to combat the disease. In Alexander the Great's era and later on in Byzantine times, not only was the consent of the patient necessary but physicians were asking for even more safeguards before undertaking a difficult operation.

Our study has shown that from ancient times

physicians have at least on occasion been driven to seek the consent of their patient either because of respect for the patient's autonomy or from fear of the consequences of their failure.

(Fournal of Medical Ethics 2001;27:59-61)
\end{abstract}

Keywords: Consent; history of medicine; medical ethics

\section{Introduction}

The doctrine of consent in medicine, in both the context of therapy and research, has been debated particularly vigorously since the second world war. The main issues discussed include the need for informed consent on the one hand, a prerequisite on which lawyers are very strict, and the necessary flexibility of its application on the other hand, on which most physicians insist, in order to meet the needs of individual patients. ${ }^{1}$ There is contemporary agreement that consent has to be informed, voluntary and given by a person who is able to understand to what he or she is consenting.

However, medical consent is not only a concept of modern times, as is often thought and believed by many authors. ${ }^{2-4}$ Our research amongst the original texts of ancient Greek and Byzantine authors revealed that consent was already an important issue at that time.

\section{Material}

In the course of his dialogues in Laws Plato refers to the issue of consent, as a means to prove the correctness of his thoughts. The Laws is considered the last work of Plato, and although it has been criticised for some weak points, because of his old age, as a totality it presents intellectual maturity, excellent knowledge of human life, and also deep feelings, which express Plato's desire for the improvement of life and true happiness for people. ${ }^{5}$ The book presents much variety, as it discusses legal issues and also historical, theological, ethical and aesthetic theories.

Plato makes a distinction between real doctors and others who are doctors' assistants who are also called "doctors". The latter might be free-born or slaves who acquired their art by experience, under the direction of their masters and not from the study of nature, as the free-born doctors learned their art and then taught it to their children and apprentices. Since patients may be either slaves or free men, the slaves were treated by doctor-slaves who did not give the slave any information about his illness nor accept any discussion about it. The free-born doctor, however, treated mainly free men. He asked for information from the patient himself and from his friends about the commencement and the course of the illness. And after having gathered all the necessary data, he informed the patient-so far as possible - about the nature of his illness and did not give him any prescription until he had gained the patient's consent, and only then did he attempt to make the patient well, soothing him with advice and preparing him persuasively. ${ }^{6}$

In Gorgias too, Plato uses the concept of persuasion of the patient by the doctor and stresses the fact that a rhetor (a person trained to speak in public) might have better results. ${ }^{7}$ This may be interpreted as meaning that persons specifically trained to obtain consent, or doctors who have specific training in this, could be better at this task.

One of the fundamental principles of Plato's philosophy is that the "knowledge of good" is inherent in every human being. According to Plato the patient knows what is "good" for him, and thus the role of the physician is to help this hidden knowledge emerge from the patient's soul by using the proper arguments. In this way, persuasion is also used by Plato in his book The Statesman ${ }^{8}$ where he says, however, that if a physician does not persuade, but forces his patient to do the right thing, though it be contrary to the written precepts, such behaviour would not be called "unscientific and baneful error". This of course gives us the more common view of the paternalistic practising of medicine in ancient Greece.

It is worth noticing that Plato requires consent from the free man in contrast to slaves. In this way 
he shows the relation of consent to autonomy of the person as the expression of his right to self determination and free will. Furthermore, the information given to patients or healthy research subjects and their ability to say "yes" or "no" to therapy or research are closely connected with what it is to be a free person. In our times, when every person is free, regardless of sex, education or social status, consent in therapy and research is necessary, even though the medical profession sometimes advocates, for the benefit of the person concerned, a modified informed or true consent.

Hippocrates, the father of scientific medicine, in his book Epidemics $I,{ }^{9}$ even before Plato, said that the patient must cooperate with the physician in combating the disease. Such cooperation could of course mean a patient had to obey all his physician's orders, but it could also mean that the patient, in order to cooperate, had to be informed and to give consent.

\section{Defensive medicine}

In ancient Greece we also see an early appearance of what we now call defensive medicine. The following cases show that not only the consent of the patient was necessary, but that physicians sometimes asked for even more safeguards before undertaking a difficult operation.

The first case relates to Alexander the Great, who suffered an almost fatal disease during his campaign in Asia. Physicians were afraid to treat him because of the severity of the disease, because of the known strictness of the emperor, and also because of the intrigues of that time. ${ }^{10}$ Finally, an eminen military physician, Philip of Acarnania, undertook the treatment of Alexander, under strong pressure from Alexander and after the emperor had openly declared his trust in him. ${ }^{11-15}$

The second case also concerns Alexander the Great. ${ }^{16}$ Alexander was seriously wounded during the siege of a town of the Mallians in India (326 BC). There are several descriptions of the emperor's operation but all historians agree on the severity of the wound and the danger to the life of Alexander. ${ }^{11-14} 17$ Curtius, ${ }^{14}$ who gives the most detailed description, says that Critobulus, a physician of distinguished skill, finally operated on Alexander. The physician was terrified at the prospect of failure and tried to avoid surgical intervention. Alexander, however, understood his hesitation and encouraged him to proceed with the operation, assuring his immunity by calling the wound a priori "incurable". "For what event or moment are you waiting, and why do you not free me as soon as possible from this pain and let me at least die? Do you perhaps fear that you may be blamed because I have received an incurable wound?"

Later on, in $578 \mathrm{AD}$, history gives us another example of defensive medicine. ${ }^{16}$ Justin II, the emperor of Byzantium, who was suffering from a mental disease and, at the same time, gout, which was probably responsible for his urolithiasis, ${ }^{18}$ in the last stages of his life contracted a serious disease which caused retention of the urine with unbear- able pains. In the account of John of Ephesus, ${ }^{19}$ this disease was caused "by the stones which his intestines produced". With cries of agony the emperor was begging the physicians to release him from the unbearable pains or even to kill him. ${ }^{190}$ The physicians were not eager to operate because they were afraid they would be punished if they failed. Finally they found a way to proceed and not be held responsible if the emperor died. Besides his reassurance that there would be no serious consequences or danger for them if he died during the operation, they requested, as John of Ephesus ${ }^{19}$ relates, that the scalpel for the operation should be given them by the emperor's own hand. That would be a gesture which declared "his own free will for the surgical intervention" according to the tradition at that time. ${ }^{20}$

The same symbolism for the seeking not only of patient consent but of patient request is found in later texts such as the Miracula Sancti Artemii (Miracles of St Artemios, 7th century) and the Life of St Lucas Stylites. Nor is this seeking of a request from a patient confined to powerful patients, as in the previous examples. The anonymous author of the Miracles of St Artemios ${ }^{21}$ praises the power of that saint to heal diseases of the testicles and hernias. At the same time, he actually blames Hippocrates and his successors, the physicians, because, when they are going to operate on someone for what we in modern times understand to have been hernias, they ask for the consent and indeed the request of the patient by their request for the symbolic gesture of the latter offering "the sword" (the lancet) to the surgeon. In this way, if God heals the patient, the doctor boasts; but if not, the doctor is not considered responsible.

\section{Authentic therapies}

Later on, in the 10th century, when subdeacon Sergios developed a swelling on the face which the physicians could not cure, he went to the Church of St Lucas Stylites, to be treated. It should be mentioned here that at that time, in the churches or the hospitals that were next to them, authentic therapies were provided by suitably specialised medical personnel. The physician who took care of him and was described as old and magnificent, hesitated and was afraid to operate because of the considerable size of the swelling and the possible complications, although the patient himself was asking with intense movements of his right hand, as he could not speak, to be operated on. At that point, Sergios took the knife and gave it to the physician who proceeded with the incision (apparently it was some kind of abscess because "a basin was filled with malodorous and rotten liquid"). ${ }^{19-22}$

The eminent Byzantine physician Paul of Aegina (7th century) also expresses his own opinion that if the result of the operation seems unpredictable, the surgeon must make the patient aware of the possible danger and only then proceed with the operation, presumably thus giving the patient an opportunity to refuse it. ${ }^{23}$ 


\section{Conclusion}

Although the issue of consent has grown immensely in importance in recent years, it seems to be a subject which philosophers and physicians faced in ancient times when, whether because of respect for their patients or because of fear of the consequences for themselves, at least some doctors sought informed consent, and even informed request, from their patients before treating them.

P Dalla-Vorgia, DrMedSc, is a Lawyer and Assistant Professor in the Department of Hygiene and Epidemiology of the Medical School of the University of Athens, Greece. She has been a member of the Bioethics Committee (CDBI) of the Council of Europe since 1984. F Lascaratos, MD, PhD, is an Assistant Professor in the Department of History of Medicine of the Medical School of the University of Athens. P Skiadas, MD, is a member of the International Hippocratic Foundation. T Garanis-Papadatos, DrMedSc, is a Research and Teaching Fellow at the National School of Public Health, Athens.

\section{References}

Anonymous. New studies in informed consent. Bulletin of Medical Ethics 1990;64:13-17.

2 King J. Informed consent. A review of empirical evidence. Institute of Medical Ethics Bulletin 1986;supp 3:1-17

3 Kour NW, Rauff A. Informed patient consent-historical perspective and a clinician's view. Singapore Medical fournal 1992;33:44-6.

4 Nelson-Marten P, Rich BA. A historical perspective of informed consent in clinical practice and research. Seminars in Oncology Nursing 1999; 15:81-8.
5 Kouchtsoglou J. The whole work of Plato, 62, Laws. 63, Epinomis. Athens: Society for Greek Publications, 1970: 5-10; 119-20.

6 Bury RG. Plato laws. London: Heinemann, 1926: 212-3; 238-9; 306-9; 454-7.

7 Lamb WRM. Plato V: Lysis, symposium, Gorgias. London: Heinemann, 1925: 290-1.

8 Fowler HN. Plato III: the statesman, Philebus. London: Heinemann, 1925: 130-3; 141-3;146-7.

9 Jones WHS. Hippocrates, vol II. London: Heinemann, 1923: 6$7 ; 165 ; 192-3$.

10 Lascaratos J, Dalla-Vorgia P. The disease of Alexander the Great in Cilicia (333 BC). International fournal of Risk \& Safety in Medicine 1998;11:65-8.

11 Arrian. Anabasis Alexandri, vol I. London: Heinemann, 1976 : 134-7.

12 Diodorus of Sicily. History, vol VIII. London: Heinemann, 1963: 204-5; 402-5.

13 Plutarch. Plutarch's Lives. Alexander, vol VII. London: Heinemann, 1971: 274-9; 402-5.

14 Quintus Curtius. History of Alexander, vol II. London: Heinemann, 1971: 99-103; 406-15.

15 Seel BM. Iuniani Iustini epitoma historiarum Philippicarum. Stuttgart: Teubner, 1985: 97-8, 114-15

16 Lascaratos J, Dalla-Vorgia P. Defensive medicine: two historical cases. International fournal of Risk $\mathcal{E}$ Safety in Medicine 1996;8 231-5.

17 Arrian. Anabasis Alexandri, vol II. London: Heinemann, 1966: $130-5$.

18 Lascaratos J. Diseases of the Byzantine emperors. Athens: J and J, 1995:115-36.

19 Ioannes von Ephesos. Historia ecclesiastica, vol III. Louvain: E W Brooks, 1964: 91-6.

20 Kislinger E. Der Kranke Justin II und die arztliche Haftung bei Operationem in Byzance. Fahrbruch der Osterreichischen Byzantinistik (F O B) 1986;36:39-40.

21 Papadopoulos-Kerameus A. Miracula sancti Artemii. St Petersburg: Varia Graeca Sacra, 1909: 38-9.

22 Delehaye H. Les saints stylites. Vita S Lucae Stylitae. BruxellesParis: Societe des Bollandistes, 1923: 219

23 Briau R. Chirurgie de Paul d'Egine. Paris: Masson, 1854: 356-7. 